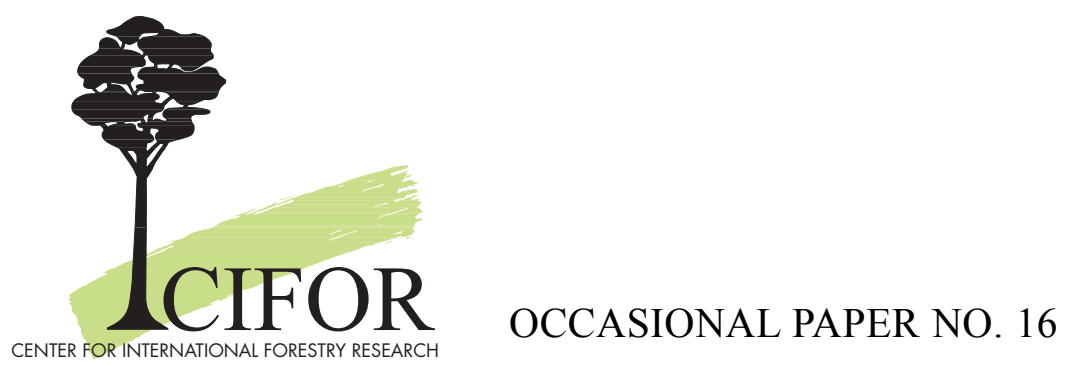

ISSN 0854-9818

Nov. 1998

\title{
Site Management and Productivity in Tropical Forest Plantations
}

A. Tiarks, E.K.S. Nambiar, and C. Cossalter

CENTER FOR INTERNATIONAL FORESTRY RESEARCH

Office address: Jalan CIFOR, Situ Gede, Sindangbarang, Bogor 16680, Indonesia Mailing address: P.O. Box 6596 JKPWB, Jakarta 10065, Indonesia

Tel.: +62 (251) 622622; Fax: +62 (251) 622100

E-mail: cifor@cgiar.org

Website: http://www.cgiar.org/cifor 


\section{CONTENTS}

Introduction 1

Environmental Capability of Tropical Plantation Forestry 2

Soil and biophysical constraints $\quad 3$

Response to management inputs $\quad 4$

Genetic potential and interaction with the environment 4

Research Strategy

Objectives

Approcah and Rationale for Treatment Selection 5

$\begin{array}{lc}\text { Experimental Design and Methodology } & 6\end{array}$

$\begin{array}{lr}\text { Project Management } & 8\end{array}$

$\begin{array}{lr}\text { Expected Outcome } & 9\end{array}$

$\begin{array}{ll}\text { Acknowledgements } & 10\end{array}$

$\begin{array}{ll}\text { References } & 10\end{array}$ 


\title{
SITE MANAGEMENT AND PRODUCTIVITY IN TROPICAL FOREST PLANTATIONS
}

\author{
Impact on soils and options for management \\ over successive rotations
}

\author{
A. Tiarks ${ }^{1}$, E.K.S. Nambiar ${ }^{2}$, and C. Cossalter ${ }^{3}$
}

\begin{abstract}
Summary
Tropical countries are expanding plantation forestry to develop sustainable wood production systems. Much of this is based on short rotations of exotic species. These systems require large capital investments, represent intensive land use and increase the demands on the soil. To develop options for maintaining or increasing productivity, a partner-project was initiated by Center for International Forestry Research (CIFOR) with three objectives: 1) evaluate the impact of soil and site management practices on the productivity of successive rotations of plantations, 2) develop management options for maintaining or increasing productivity and 3) where it is appropriate strengthen local institutional capacity to respond to new problems and opportunities. The project focuses on the critical inter-rotational phase of management: harvesting, site preparation, and early stand development. A core set of treatments selected to create a range of impacts on organic matter and nutrients supply intensities will be included at all locations. Optional treatments tailored to each site will be added as required by local management, and soil and stand considerations. Each location will carry out a self-contained experiment that will produce scientifically valid results on its own merit. All experiments are networked to integrate the information so underlying processes can be understood and options for science based management developed. All sites are expected to be valuable reference sites for long-term investigations.
\end{abstract}

\section{INTRODUCTION}

Natural forests of the tropics will not be able to sustain increasing domestic and international demands for wood and wood products. Environmental concerns, social pressures and the rapidly diminishing resource all constrain the harvest of timber from natural forests. Tropical countries must move towards sustainable wood production systems on a more limited land area through plantation forestry. Forests range in a continuum from wilderness areas to plantations, depending on their function, use and the goals of management (Nambiar 1996a). While wilderness or reserve forests satisfy desired conservation values, plantations are necessary on limited and defined land areas to meet increasing demand of wood products including firewood, pulpwood, and sawlogs (Brown et al. 1997). Plantation forestry not only offers opportunities for meeting wood demands and reducing deforestation by decreasing pressures on natural forests, but can restore degraded soils and enhance biodiversity (Parrotta 1992, 1995).

Nambiar (1996a) identified the distinctive features that characterise plantation management in comparison with native forest management. These include: (i) higher rates of production per unit area and thus greater demand on site; (ii) higher intensity and frequency of disturbance because of shorter rotations; (iii) opportunity for changing the genetic stock; (iv) feasibility for applying intensive management for ameliorating site limitations (eg: soil fertility); (v) continuous scope for stand management; and (vi) economic return from investments from a market-oriented management. These considerations, and global demand for wood have promoted rapid expansion of plantation forestry in the subtropics and tropics (Brown et al. 1997).

Use of short rotation, high yielding plantations to grow a sufficient supply of the renewable resource has several advantages and these are expanding. Because of the high yields, the area affected is smaller and concentrated, leaving more room for other types of land use including natural forests. Tree species can be established to enhance the productivity of lands that have been degraded by deforestation. Selected species can be planted and harvested to meet age, size and quality specifications to match the needs of the final product such as paper. As global market conditions change, the

\footnotetext{
${ }^{1}$ Southern Research Station., USDA Forest Service, 2500 Shreveport Highway, Pineville, LA 71630 USA

${ }^{2}$ CSIRO Forestry and Forest Products, P.O. Box E4008, Kingston, Canberra, ACT 2604, Australia

3 CIFOR, P.O. Box 9596 JKPWB, Jakarta 10065, Indonesia
} 
species or size of log can be quickly changed to meet the specifications of new products. Finally, the development of improved forest planning and operations can minimise site impacts, increase utilisation and minimise or avoid adverse environmental effects.

Productivity of plantations needs to be high and sustainable because of the large initial investments required. Thus, plantations must be economically viable whether publicly or privately owned. Also, wood consuming mills including pulp and paper facilities are established with the expectation of sufficient raw materials being reliably supplied from an area within reach of the mills (Sunderlin and Resosudarmo 1996). Apart from these resource and economic considerations, plantation forestry also must develop without adverse impact on the environment.

Plantation forestry is new in many tropical areas and yields vary considerably across ecosystems (Table 1). In many locations where plantations have only recently appropriate species-site matching and when management prescriptions are effective plantations usually remain healthy and productive. Short rotations and intensive harvesting would increase nutrient losses from the site by removal in the wood and other losses (Fölster and Khanna 1997; Gonçalves et al. 1997).

\section{ENVIRONMENTAL CAPABILITY OF TROPICAL PLANTATION FORESTRY}

Plantation management and opportunities for improvement on a worldwide scale have been described in recent books (Evans 1992; Nambiar and Brown 1997b). Nambiar and Brown (1997b) point out the many factors that contribute to low and varying yield in tropical plantations. These reviews show major gaps in knowledge about the environmental capabilities in countries where plantations of high yielding, short rotations are being established to supply the pulp and wood needs of the local population as well as for export. There is considerable expansion of such plantation

Table 1. Productivity of main plantation genera in selected tropical countries (Brown et al. 1997)

\begin{tabular}{|c|c|c|c|c|}
\hline Species & Region & Country & Rotation length (yr) & $\operatorname{MAl}\left(\mathrm{m}^{3} \mathrm{ha}^{-1} \mathrm{yr}^{-1}\right)$ \\
\hline \multirow[t]{5}{*}{ Eucalypts } & America & Brazil & 8-10 & $18-20$ \\
\hline & Africa & Burundi & 8 & $1-2$ \\
\hline & & Congo & 7 & 30 \\
\hline & & Rwanda & 8 & 8.5 \\
\hline & & South Africa & $8-10$ & $18-20$ \\
\hline \multirow[t]{6}{*}{ Pines } & America & Brazil & $16-25$ & $15-25$ \\
\hline & & Venezuela & $10-20$ & 10 \\
\hline & & Chile & $20-30$ & 24 \\
\hline & Africa & Malawi & $20-25$ & 17 \\
\hline & & Madagascar & $15-18$ & $6-10$ \\
\hline & & Mozambique & $18-25$ & 11 \\
\hline \multirow[t]{3}{*}{ Teak } & Asia & Bangladesh & 60 & $2.6-3$ \\
\hline & & India & 70 & 2.5 \\
\hline & & Indonesia & $50-70$ & $1.3-2$ \\
\hline
\end{tabular}

been established, little is known about the potential capabilities for increasing productivity as well as potential problems that may limit yields (Brown et al. 1997). The great majority of planted area is based on exotic species chosen for their capacity to grow rapidly and produce wood of appropriate quality, especially pulping properties. In some cases sites can support wood production with proper management, but elsewhere there are serious problems. The extent to which intensively managed plantations with relatively narrow genetic bases are susceptible to disease, insects, and natural disasters is not well evaluated. However, where there have been forestry in Asia, Africa and South America (Cossalter 1993; Brown et al. 1997). There is a long history of teak and eucalypt plantations being used for wood products in some tropical countries. However, plantings of fast growing native and exotic species is new in much of the tropics and we only know little about the potential capabilities for increasing productivity as well as potential problems that may limit yields in the long-term.

The risk to sustainability of plantation forestry depends on the degree of alignment of interdependent variables that include ecological capability of the site, intensity 
of management, impact on soil, water and other environmental values, economic benefit and social goals (Nambiar 1996b; Nambiar and Brown 1997a). Of these, ecological capability is the only one tied directly to site. Nambiar and Brown (1997a) define the ecological capability of a site as:

1) bounded by the inherent soil and biophysical constraints,

2) the responsiveness of the soil to management inputs,

3) the genetic potential of the species and their interaction with the environment of the site.

\section{Soil and biophysical constraints}

There are six major forest soil groups in humid tropics, but on landforms suitable for short rotation tree crops, the majority of the soils are classified as Acrisols, Ferralsols, or Podzols in the World Reference Base for Soil Resources (Kauffman et al. 1998). The major soil groups available for plantation forestry are characterised by low amounts of weatherable minerals, low cation exchange capacity, low to very low base saturation, and high levels of exchangeable aluminum (Lal 1997; Gonçalves et al. 1997). The Acrisols and Ferralsols are well or moderately well drained, and usage for perennial crops may be severely limited by low available water during part of the year. Organic carbon contents range from $1 \%$ to $2 \%$ in the surface $20 \mathrm{~cm}$ and $0.5 \%$ at 100 $\mathrm{cm}$ (Kauffman et al. 1998). The most critical accumulations of organic matter are in the litter layer which is crucial for maintaining nutrient supply, water retention, and structural stability.

The major limitations to using tropical soils for short rotation tree crops are low nutrient reserves, poor nutrient retention ability and susceptibility to drought. Because of the importance of the litter layer to nutrient supply and soil structure, disturbance of the surface should be kept to a minimum to maintain productivity. Maintenance of the litter layer or other vegetative cover is necessary in limiting erosion and keeping a suitable soil moisture balance (Spaargaren and Deckers 1998).

Despite the high and monsoonal rainfall received in parts of the tropics, soil water deficit can be a recurring constraint on productivity on many sites in subtropics and tropics (Gonçalves et al. 1997, Landsberg 1997). In the semiarid and arid tropics, water stress may limit rates of growth below commercially viable levels. Soil management for conserving available water is a critical consideration.
To compound the problems of fragile soil, much of the land available to forestry was cleared for other land uses that failed. These past practices may have reduced the productivity of the soil by degradation (Oldeman 1994). Past land uses that have degraded the chemical and physical characteristics of sites will also affect their environmental capability for plantation development and economic sustainability.

The loss of nutrients and organic matter is a very significant factor in chemical degradation (Fölster and Khanna 1997). Loss of nutrients varies with management practices and can have a dramatic effect on the growth of the next stand. In Sabah, Malaysia, tractor logging and slash burning resulted in much higher losses of inorganic nutrients compared to manual wood extraction and no burning (Nykvist et al. 1994). Biomass of the subsequent Acacia mangium plantation at age 3.8 years was only $30 \mathrm{Mg} \mathrm{ha}^{-1}$ in the tractor logged and burned areas, compared to $50 \mathrm{Mg} \mathrm{ha}^{-1}$ after low impact logging. Nutrients lost by removal or leaching can be replaced by fertilisation, but best results are usually obtained when fertilisation is combined with other practices such as weed control or site preparation. This is especially true on sites where grass competition such as Imperata cylindrica has invaded after forest clearing and must be controlled to re-establish tree species (Otsamo 1998).

Physical degradation may be soil compaction caused by the use of heavy equipment or loss of soil structure when litter layers are disturbed. The effect of soil compaction and other soil disturbances can be severe if operations are not properly managed. In Cameroon, hand clearing increased soil bulk density from 1.16 to $1.30 \mathrm{~g} \mathrm{~cm}^{-3}$ in the surface $10 \mathrm{~cm}$ (Ngeh et al. 1995). Use of heavy tractors and removal of all logging residue not only increased the bulk density of the surface to 1.53 $\mathrm{g} \mathrm{cm}^{-3}$, but significantly increased bulk density to the 55 $\mathrm{cm}$ depth. However, not all logging and site preparation treatments impact physical properties negatively. Nine years after planting, the physical properties of soil in plantations of Eucalyptus spp. and Paraserianthes falcataria were similar to soils compared to soils in nearby undisturbed and selectively logged dipterocarp forests in East Kalimantan (Wenzel et al. 1995). Bulk densities were slightly higher under the eucalypts and saturated hydraulic conductivities were higher at $30 \mathrm{~cm}$ depths under both plantation species. Apparently, these changes in physical properties were too small to affect the growth or distribution of tree roots (Murach et al. 1998). These two extremes demonstrate that the effects 
Figure 1: Harvest and Intensity of Management (Nambiar and Brown 1997a)

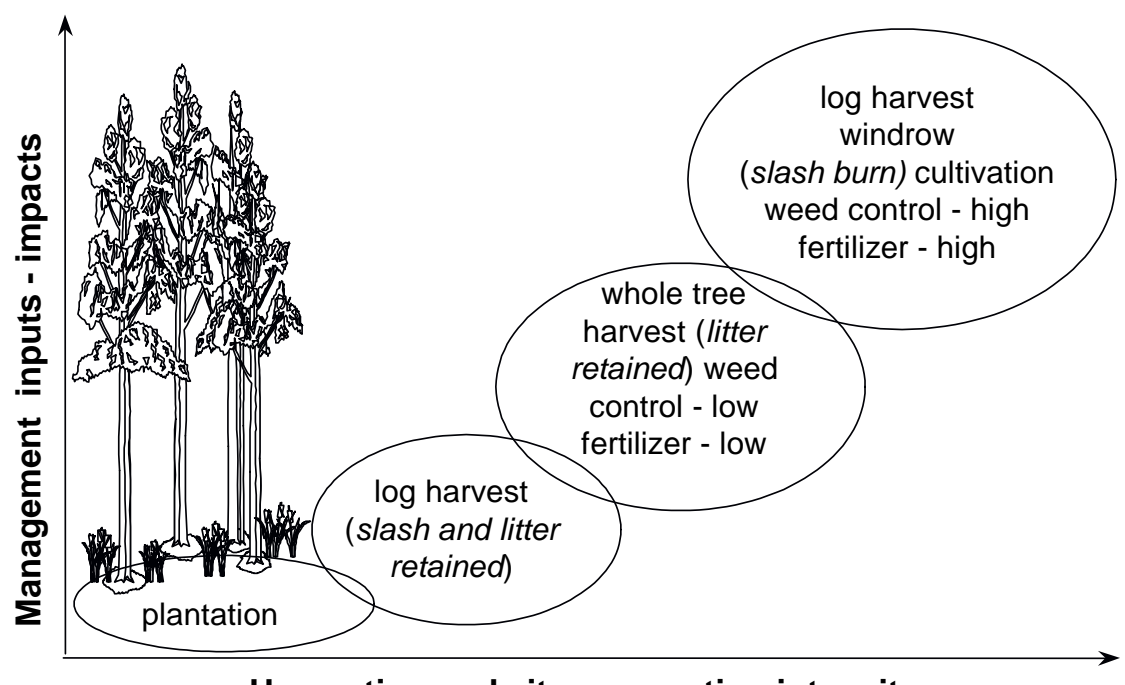

Harvesting and site preparation intensity

of planting, tending and harvesting on the physical properties of the soils will be highly dependent on the soils and the type of equipment used. Studies designed to study changes in physical properties need to be adapted to the local soil conditions and to the type of logging equipment that is in use or may be used in the future.

\section{Response to management inputs}

The greatest impact from management inputs are due to operations associated with harvesting, site preparation, planting and early silviculture, including fertilisation and weed control (Nambiar and Brown 1997a). Intensity of logging and site preparation methods affect the types and amount of slash remaining on the site. While the bole wood is usually of greatest economic interest, other biomass may be removed as well. Tops may be utilised for firewood, piled within the plantation or burned in order to improve regeneration, facilitate weed control or lower fire hazard. Nutrient distribution in trees is affected by age, species and site, but generally the foliage and branches contain a major portion of the nutrients, especially compared to their total biomass (Fölster and Khanna 1997; Gonçalves et al. 1997). The litter layer is an important source of nutrients and organic matter and their fate during forest management has major impacts on nutrient cycling, especially in short rotation forestry (O'Connell and Sankaran 1997). However, interactions of organic matter with other components in the system may complicate the response to biomass additions (Nambiar 1996a). For instance, the amount of nitrogen in soil organic matter is much greater than in the biomass so loss of nitrogen depends more on the amount of soil $\mathrm{N}$ mineralised than $\mathrm{N}$ removed in logging slash (Smethurst and Nambiar 1990a). By measuring selected soil properties and tree growth, the processes involved may be understood. Then slash management decisions can be based on expected biological responses. A conceptual basis for relating harvesting and site management intensity and various operational practices is described in Fig. 1.

\section{Genetic potential and interaction with the environment}

Most plantations consist of a limited number of fast growing and exotic species including eucalypts, pines, acacias, and teak, although there are efforts to identify appropriate local species (Brown et al. 1997). With selection, breeding, and vegetative propagation, genetic gain has been rapid and further improvement is expected as provenances and even individual genotypes are matched to the site (Boyle et al. 1997). Besides environmental stress such as frosts, diseases and insects, gains in productivity may be made on selections adapted to site conditions. Species with fast early growth resulting in rapid crown closure performed best when 
reforesting Imperata cylindrica grasslands in Indonesia (Otsamo et al.1997). However, other species including those locally indigenous, may be more suitable when subsequent rotations are established. In South Africa, performance of some provenances of Eucalyptus camaldulensis was greater in soils which had a seasonal water table, other provenances were better adapted to deeper drier soils and the performance of others was not affected by the site (Ellis 1995). Matching site and species can increase the amount of nitrogen fixed by some species. While there are prospects for judicious mixtures of $\mathrm{N}$-fixing and non- $\mathrm{N}$-fixing species in plantation forestry, such a strategy also needs welldeveloped site and stand management practices (Binkley and Giardina 1997). Because changes in species or gains from genetic improvement occur in parallel with operational plantations, they may make productivity comparisons between rotations difficult. However, genetic gain through tree breeding is not a panacea for sustained productivity. Genetic gains cannot be realised operationally unless plantation management is carried out under sound site-soil and stand management, and over-zealous claims about the benefit of genetic improvement need to be treated with caution (Nambiar 1996b).

\section{RESEARCH STRATEGY}

Promotion of sustainable plantation forestry in subtropical and tropical countries through relevant research and application is an important objective of CIFOR. Discussion between some key international scientists and plantation managers was used to identify this research theme and to focus this project to increase adoption by users. A draft plan setting out the aims and core research strategy was developed by the authors (with Dr R.J. Myers, International Board for Soil Research and Management (IBSRAM)) and sent to potential participants and some scientists for comments. After revision, a workshop was held at the Forest Research Institute Malaysia during November 1995 with researchers and managers from institutions which had expressed interest in participation. The objectives, approach, coordination and methodology were presented and discussed at the workshop. Comments from the workshop were incorporated into a final plan. This plan is being implemented after any necessary adaptation to suit local conditions. At the heart of the plan is the concept of well designed, process oriented network of on-site research founded on international partnership and collaboration.

\section{OBJECTIVES}

The general objective of this project is to develop sound scientific information and promote the application of it to develop management options and demonstrate the value of sound forestry practices under different environments in a multi-national context.

At each location, the experiment would be designed to meet the following specific objectives:

1) Evaluate the impact of soil and site management practices on the productivity of successive rotations of plantations. Crop cycles may consist of plantations grown for pulp wood, poles, sawn timber or fuel wood. The treatments applied should represent (1) the most generic and extremes of management practices so the boundaries of impacts can be identified and (2) current practices including the "local best practices" and improved genetic material. Impacts of the treatments will be measured as changes in yield and pertinent soil and site factors.

2) Develop management options for maintaining or increasing productivity. Sufficient information will be gathered so that the impact of each option on soil and associated environment can be explained. This information should allow managers to select and adapt options to meet their specific circumstances and to demonstrate the consequences of desirable and undesirable practices.

3) Strengthen local institutional capacity to respond to new problems and opportunities. The partnership will enhance the experience and capability of all participating organisations by sharing information. Local partners should be better equipped to offer quick response, local knowledge and long-term institutional memory of changing social, economic and ecological conditions than outside organisations.

\section{APPROACH AND RATIONALE FOR TREATMENT SELECTION}

Productivity of a plantation is influenced by management practices through out the life of the rotation. But in practice, no single project can deal with all the complexities of production through the crop cycle effectively.

As noted earlier, this study focuses on the critical interrotation phase of harvesting, site preparation and stand establishment (Fig. 1). Harvesting, site preparation, and early stand-tending practice, from planting to canopy 
closure, have lasting and major effects on productivity of successive crops and on the off-site environment (Dyck et al. 1994; Nambiar 1996a).

Well designed field experiments, with appropriate treatments and measurements, will be used to obtain information to improve the understanding of the processes which influence stand productivity. Treatments are selected to evaluate the effects of management practices on productivity and the soil resource base over successive rotations. Measurement of on-site parameters will be emphasised, but the offsite impacts will be measured if appropriate to the specific site and partner's capacity to undertake additional objectives. In the long-term, the results will be quantitatively assessed and evaluated in sequential phases beginning three to five years after commencing the project. At each assessment period, the results will be compared across all sites to maximise the generic and scientific value of the information. Then at each location, a package of practices can be developed in close interaction with managers to improve the forest management.

Through partnerships and co-operative projects, a network of planned studies will be located gradually in a range of environments in the tropics/subtropics. The study is structured to focus on research and management needs by using a network of research plots established in operational plantations where measurements can be integrated. The self-contained and scientifically designed individual studies are linked to a network to increase the exchange of information in a mutually rewarding partnership. Planned studies are able to meet three conditions required to supply convincing evidence of productivity changes over long periods and the possible explanations for such change (Powers et al. 1990). First, they include standard control treatments for comparing the effects of other treatments. Second, they allow measurement of the tree crop itself, rather than some surrogate such as soil organic matter. Third, well-designed experiments with proper treatments established in space and time provide robust evidence of the productivity change and factors influencing them. By using one rotation or more as the experimental period, variation caused by climate or other random effects are minimised.

The experimental layout and selection of treatments are designed to evaluate the effects of management practices on productivity and the soil resource base over successive rotations. Site management practices during the inter-rotation phase can determine whether the productivity of the next rotation will be maintained or improved - it is a period of high opportunity and high risk. Nambiar and Brown (1997a) suggest plantation forestry offers opportunities and potential management problems on a site through:

1) high rates of production with corresponding increases in site impacts,

2) frequent disturbance because of short rotations,

3) opportunity to improve genetic stock, increasing production even more,

4) intensive soil management during establishment, and

5) weed control, fertilisation and thinning throughout the rotation.

Poor harvesting practices and site preparation can be detrimental to productivity (e.g. Balneaves et al. 1991; Sim and Nykvist 1991; Nambiar 1996a). Without good management, organic matter and nutrients may be depleted, and soil properties damaged through processes including compaction and erosion. Removal of biomass during harvest is chosen as the common theme in this study because:

1) slash retention is controlled by management in all settings and is thus a universal treatment, and

2) while soil organic matter may not be directly linked to productivity, indirect effects including nutrient removal, microclimate changes, and soil aggregation may affect productivity.

\section{EXPERIMENTAL DESIGN AND METHODOLOGY}

The design of the project is to include: (i) a set of treatments based on a common principle at all locations and (ii) additional treatments tailored to each site, depending on local management concerns, soil and forest conditions and productivity objectives. Each experimental site should be self-contained in terms of objectives and explanatory capacity. It will be of most immediate benefit to local forestry who would also contribute to the pool of knowledge from which all participants would benefit. The common measurements will allow comparison of the results between sites and better understanding of the processes. The experiment will be located on sites with soils that are representative of a wide area. Treatments, plot sizes and sampling will be designed to detect a $15 \%$ to $20 \%$ difference in productivity. This approach is based on the experience of research on sustained productivity in other ecosystems 
(e.g. Powers et al. 1990; Smethurst and Nambiar 1990a, b).

The common treatments will simulate different harvesting intensities leading to four levels of organic matter or above-ground biomass left on site (BL). These are:

$\mathrm{BL}_{0}$ All above ground organic matter including the crop trees, understorey, slash and litter is removed. Where present, the soil organic matter (organic residue that is decomposed beyond recognition) on the surface is not removed.

$\mathrm{BL}_{1}$ Whole tree harvest. All above ground components of the commercial sized crop trees are removed with minimum practical disturbance to site.

$\mathrm{BL}_{2}$ Stemwood + bark harvested. Stand is felled and the tops and branches are cut and retained at the stump. Only the commercial sized stems and bark on them is removed. All other organic residue is left with minimum disturbance.

$\mathrm{BL}_{3}$ Double slash. Branches, leaves and other noncommercial components (excluding litter) of the trees from the $\mathrm{BL}_{1}$ treatment are transported and distributed evenly over the plot.

SC (Standing Crop): an uncut area close to and representative of the harvested stand will be left in a sufficient sized block as a control for comparison and for measuring changes in soil and other site properties. The site-specific treatments: At each site a set of treatments will be selected on their potential to enhance productivity, increase the understanding of basic process, and to answer questions that may be posed in the future. Examples of variables that may be used are:

1) Best current practices: A package of practices based on the best current knowledge and practical experience on similar sites.

2) Best practices: Treatments based on the best scientific knowledge or new innovations. These may represent practices aimed at potential growth (biological maximum) regardless of current economics.

3) Soil compaction: Harvesting practices that might influence soil density and strength from harvesting equipment and amelioration from tillage. Levels could be reduced bulk density from tillage, normal bulk density by using non-impact harvest methods, and increased bulk density by heavy harvesting equipment.

4) Nutrient inputs: Treatments including fertiliser application, intercropping with legumes, and organic residue (including waste) applications. Levels may be two rates of two nutrients, several rates of one or with and without intercropping.

5) Species mixture: Treatments, either spatially or temporally which may include mixed species planting (eg: Acacia and Eucalyptus) a short rotation nurse crop to establish another or growing an annual crop between rotations of trees. Levels may be presence or absence of a second species.

6) Slash burn: Burning as a site preparation technique. Levels could be different amounts of fuel (biomass) and/or different burning intensities, depending on weather conditions.

7) Measurements of off-site impacts: In some sites, depending on the local skills and resources, impacts of treatments in off-site properties including soil erosion, water chemistry, and water yield may be included. and

8) Genetic improvement: The common and site specific treatments are to be planted with stock of "currently used" genetic stock. Additional treatments to compare the growth gain or loss from specific genetic material may be included.

One of the common biomass left treatments would be used as the basal treatment on which site-specific treatments would be applied.

Planting stock: Choice of planting stock is an issue in experiments that aim to compare productivity across rotations. At the same time, the overall value of the research to management might be reduced by strict adherence to old and unimproved genetic stock, because at each rotation management is likely to use the best available genetic stock at that time. Therefore, it was decided that each site would use the genetic stock operationally used for planting by the organisation. Every effort should be made to obtain $100 \%$ survival.

Measurements: There will be a common set of measurements made on all sites using standard methods. These methods will be discussed and agreed to in the site plan developed by the partners and reviewed by the Scientific Advisory Panel (SAP) (See description under Project Management). These detailed descriptions of the measurements and methods will be added to the site plan as appendices. The minimum measurements will include: 
1) Standing crop: Trees will be sampled in sufficient detail to estimate the mass of wood and bark in the main stem, branches, foliage, understorey and litter. Sub-samples will be collected for the determination of nutrients in each class of biomass. This information is essential for calculation of the biomass and nutrients left on the plots or removed by the harvest.

2) Tree growth: The height and diameter of all trees on each treatment plot will be measured at periodic intervals during the rotation. Volume and biomass equations will be developed from sample trees so these can be estimated from the height and diameter data. Foliage samples will be collected at specified times for characterising stand nutrition.

3) Understorey and forest floor: The biomass and species composition of the understorey will be measured periodically. Litterfall will be measured using litter traps, while the forest floor will be sampled annually for mass and nutrient determinations. Studies of litter decomposition using litter bags or similar methods will be encouraged.

4) Soils: Bulk density and hydrological properties will be measured once per rotation, in the months immediately following replanting. At the same time, samples will be collected through the soil profile for chemical analysis. Depth to which soil will be collected will depend upon the profile features. Measurements will include total organic carbon and nitrogen, $\mathrm{pH}$, exchangeable cations including $\mathrm{Al}$ and exchangeable acidity, electrical conductivity, available nitrogen and phosphorus. Total and labile organic carbon, total and anaerobic nitrogen, and available phosphorus determinations will be made on surface soil samples collected at three year intervals or at mid-rotation. Soil strength will also be measured at those times using a recording penetrometer. Measurements that increase the understanding of processes such as nitrogen mineralisation will be encouraged. All soil samples are to be properly stored (archived) as they are expected to be valuable reference samples for longterm analysis in changes in soil properties.

5) Climatic data: A weather station will be established on or near the site for daily measurements. Rainfall, pan evaporation, wet and dry bulb temperatures and solar radiation will be measured at a specified time each day. Maximum-minimum temperatures will also be recorded. Additional parameters that may be required for modeling the environment will be considered.
6) Record of operations: A detailed log will be kept for recording all operations and events that may affect the productivity of the plantation. Examples are vegetation (weed) management, kinds and amounts of fertilisers, pruning, insect or fungi attacks or fires. The data should be collected in a manner that will improve interpretations, including economic analysis.

Management of experiment: Long-term value of these experiments, and meaningful interpretation of results from them depends upon the care and precision which experiments are managed and cared for. Key aspects include: full stocking, appropriate vegetation control, protection from grazing and other damage, regular supervision and reliable and detailed record keeping.

\section{PROJECT MANAGEMENT}

Implementation of and successful outcome from this project are fundamentally dependent upon the local leadership and commitment of partners. Co-ordination and facilitation is provided by the Center for International Forestry Research (CIFOR) through a Scientific Advisory Panel (SAP), established by CIFOR. CIFOR will negotiate with potential partners the type of assistance and funds required for these activities. Each partner may enter into bilateral or other collaborative arrangements with national or international organisations to advance their objectives. CIFOR, with SAP, will organise workshops including existing partners, potential new partners and invited scientists as required for co-ordination of the research exchange of information as well as for integration and dissemination of results.

Partners are the "national forestry research systems" that are responsible for the studies within their countries. They may be public or private forest organisations who have the required commitment, resources and technical expertise either on their own or in collaboration with research institutes, universities and non-government organisations. The partners are ultimately responsible for all aspects of the study within their jurisdiction including location of sites, collection and analysis of samples, application of treatments, plot maintenance, and data collection. They also own the data from their site.

The SAP is a group of scientists invited by CIFOR to develop this plan and advise on the scientific aspects of this study on an ongoing basis. The members are chosen 
on the basis of their experience and record of contribution to research on sustained productivity. Each partner has the right to publish, or use the results from their site in a manner that would benefit them. Data shared during workshops between the members of planned activities and methods should not be used by others without the written agreement of the respective partners. CIFOR and SAP may use the data for comparative analysis and integrated reporting with adequate recognition or acknowledgement of the source of data.

At the workshops, all active partners will meet to exchange information and share data as required. All partners are expected to gather and report to CIFOR the required data in a manner consistent with the requirements of the study and to foster dissemination of information between partners. Workshops will also be used to integrate the data so that the underlying processes can be understood and management options developed. To avoid dissemination of sensitive, preliminary, or incorrect information, these meetings will be open only to the partners, CIFOR, SAP and invited guests. Sensitivity of the partner's circumstance will be taken into account in the development of this project and data can be identified with a particular partner. The release of information will systematically be subject to the approval of the concerned party. The overall aim of this project is also to strengthen long-term, creative links between research providers and stakeholders (plantation owners and managers).

\section{EXPECTED OUTCOME}

The formal way of reporting results from the project will be through scientific journals. At each location, the study is designed to be a robust experiment that will produce results which can be published on its own, if the partner desires. At regular intervals, the data will be integrated by groups of partners and the SAP. These results will be published in international journals with due recognition given to all contributors. Where appropriate, SAP members will assist the project through sharing of information and their experience with relevant partners.
This study will be a well designed demonstration of the problems and prospects of plantation productivity. Because of the evaluation of the effects of soil and site management practices on the productivity of plantations, the results will be useful for short and long-term planning. The integrated results from the network will be sufficiently robust to use in feasibility studies at new locations. Although the aim of this project will be fully achieved only over long-term (25 or more years), meaningful and useful results that will improve our knowledge and assist management should be available in a short time (three years). Earlier results would also identify critical processes that control productivity and fruitful avenues for further research and development. Researchers may be able to use this project to demonstrate the value of their research and its international significance to their own managers and sponsors of research and development.

Options for maintaining or increasing productivity in plantations will be developed and communicated to land owners, managers and public organisations. Sufficient information will be gathered so the risks and associated environmental impact of each option can be assessed. Because the treatments imposed in the study are designed to cover the extreme management practices, options to correct any problems or to efficiently increase the productivity will become apparent from the results. The development of criteria and indicators for plantation productivity is not a goal of this project. However, the information gathered over the life of the project can be used a foundation on which to build soil quality and related standards.

Local institutions including universities, governmental forestry organisations and land managers including private companies and co-operatives will be strengthened by the experience gained by working with other partners and from shared experience. All parties are likely to benefit from the overall pool of information and greater opportunities for transporting results to meet individual operations. Land managers will benefit from immediate access to productivity data from their own plantations. It is also envisaged that scientific access will be strengthened through training or other assistance. 


\section{ACKNOWLEDGEMENTS}

We thank Dr. R.J. Myers (IBSRAM) for his valuable contribution to the preparation of the initial research plan of this study.

\section{REFERENCES}

Balneaves, J.M., Skinner, M.F. and Lowe, A.T. 1991. Improving the re-establishment of radiata pine on impoverished soils. In: Dyck, W.J. and Mees, C.A. (eds.) Proceedings IEA/BE T6/A6, 137-150, Bulletin No. 161. Forest Research Institute, Rotorua, New Zealand

Binkley, D. and Giardina, C. 1997. Nitrogen fixation in tropical forest plantations. In: Nambiar, E.K.S. and Brown, A.G. (eds.) Management of soil, water and nutrients in tropical plantation forests, 297-337. Australian Centre for International Agricultural Research (ACIAR), Monograph 43, Canberra.

Boyle, T.J.B., Cossalter, C. and Griffin, A.R. 1997. Genetic resources for plantation forestry. In: Nambiar, E.K.S. and Brown, A.G. (eds.) Management of soil, water and nutrients in tropical plantation forests, 25-63. Australian Centre for International Agricultural Research (ACIAR), Monograph 43, Canberra.

Brown, A.G., Nambiar, E.K.S. and Cossalter, C. 1997. Plantations for the tropics - Their role, extent and nature. In: Nambiar, E.K.S. and Brown, A.G. (eds.) Management of soil, water and nutrients in tropical plantation forests, 1-23. Australian Centre for International Agricultural Research (ACIAR), Monograph 43, Canberra.

Cossalter, C. 1993. Current trends of reforestation in the tropical countries of Asia and the Pacific. Proceedings. International Workshop BIO-REFOR, Yogyakarta, 37-42.

Dyck, W.J., Cole, D.W. and Comerford, N.B. 1994. Impacts of forest harvesting on long-term site productivity. Chapman and Hall, London. $371 \mathrm{p}$.

Ellis, F. 1995. Drought resistance of eucalyptus species/provenances on sandy soils along the dry South African Cape west coast -- a case study. In: Proceedings International Congress on Soils of Tropical Forest Ecosystems, 29 October-3 November 1995, Balikpapan, Indonesia, Vol 4: 106-114. Mulawarman University Press, Samarinda.

Evans, J. 1992. Plantation forestry in the tropics. 2nd ed. Clarendon Press, Oxford. 403 p.

Fölster, H. and Khanna, P.K. 1997. Dynamics of nutrient supply in plantation soils. In: Nambiar, E.K.S. and Brown, A.G. (eds.) Management of soil, water and nutrients in tropical plantation forests, 339-378. Australian Centre for International Agricultural Research (ACIAR), Monograph 43, Canberra.

Gonçalves, J.L.M., Barros, N.F., Nambiar, E.K.S. and Novais, R.F. 1997. Soil and stand management for shortrotation plantations. In: Nambiar, E.K.S. and Brown, A.G. (eds.) Management of soil, water and nutrients in tropical plantation forests, 379-417. Australian Centre for International Agricultural Research (ACIAR), Monograph 43, Canberra.

Kauffman, S., Sombroek, W. andMantel, S. 1998. Soils of rainforests: Characterisation and major constraints of dominant soils in the humid tropics In: Schulte, A and Ruhiyat D. (eds.) Soils of tropical forest ecosystems characteristics, ecology and management, 9-20. Springer, Berlin.

Lal, R. 1997. Soils of the tropics and their management for plantation forestry. In: Nambiar, E.K.S. and Brown, A.G. (eds.) Management of soil, water and nutrients in tropical plantation forests, 97-123. Australian Centre for International Agricultural Research (ACIAR), Monograph 43, Canberra.

Landsberg, J.J. 1997. The biophysical environment. In: Nambiar, E.K.S. and Brown, A.G. (eds.) Management of soil, water and nutrients in tropical plantation forests, 65-96. Australian Centre for International Agricultural Research (ACIAR), Monograph 43, Canberra.

Murach, D., Ruhiyat, D., Iskandar, E. and Schulte, A. 1998. Fine root inventories in dipterocarp forest and plantations in East Kalimantan, Indonesia. In: Schulte, A and Ruhiyat D. (eds.) Soils of tropical forest ecosystems characteristics, ecology and management, 186-191. Springer, Berlin.

Nambiar, E.K.S. 1996a. Sustained productivity of forests is a continuing challenge to soil science. Soil Science Society of America Journal 60: 1629-1642. 
Nambiar, E.K.S. 1996b. Sustained productivity of plantation forests is a continuing challenge to tree improvement. In: Dieters, M.J., Matheson, D.G., Harwood, C.E. and Walker, S.M. (eds.) Tree improvement for sustainable tropical forestry. Proceedings QFRI-IUFRO Conference, Caloundra, Queensland, Australia 27 October - 1 November 1996, 6-18. Queensland Forestry Research Institute, Gympie.

Nambiar, E.K.S. and Brown, A.G. 1997a. Towards sustained productivity of tropical plantations: Science and practice. In: Nambiar, E.K.S. and Brown, A.G. (eds.) Management of soil, water and nutrients in tropical plantation forests, 527-557. Australian Centre for International Agricultural Research (ACIAR), Monograph 43, Canberra.

Nambiar, E.K.S. and Brown, A.G. (eds.) 1997b. Management of soil, water and nutrients in tropical plantation forests. Australian Centre for International Agricultural Research (ACIAR), Monograph 43, Canberra. 571 p.

Ngeh, P., Furtey, P.A. and. Grace, J. 1995. Effect of land clearing methods on soil physical and chemical properties in a lowland tropical forest at Mbalmayo, Cameroon. In: Proceedings International Congress on Soils of Tropical Forest Ecosystems. 29 October-3 November 1995, Balikpapan, Indonesia, Vol. 2: 103-122. Mulawarman University Press. Samarinda.

Nykvist, N., Grip, H., Sim, B.L., Malmer, A., and Wong, F.K. 1994. Nutrient losses in forest plantations in Sabah, Malaysia. Ambio 23:210-215.

O'Connell, A.M. and Sankaran, K.V. 1997. Organic matter accretion, decomposition and mineralisation. In: Nambiar, E.K.S. and Brown, A.G. (eds.) Management of soil, water and nutrients in tropical plantation forests, 443-480. Australian Centre for International Agricultural Research (ACIAR), Monograph 43, Canberra.

Oldeman, L.R. 1994. The global extent of soil degradation. In: Greenland, D.J. and Szaboics, I. (eds.) Soil resilience and sustainable landuse, 99-118. CAB International, Wallingfored, U.K.

Otsamo, A. 1998. Effect of fertilisation on establishment and early growth of tree plantations on Imperata cylindrica grassland. In: Schulte, A and Ruhiyat D. (eds.) Soils of tropical forest ecosystems - characteristics, ecology and management, 137-143. Springer, Berlin.

Otsamo, A., Adjers, G., Hadi, T.S., Kuusipalo, J. and Vuokko, R. 1997. Evaluation of reforestation potential of 83 tree species planted on Imperata cylindrica dominated grassland. New Forests 14:127-143.

Parrotta, J. 1992. The role of plantation forests in rehabilitating degraded tropical ecosystems. Agricultural Ecosystem and Environment 41:115-133.

Parrotta, J. 1995. Influence of overstory composition on understory colonisation by native species in plantations on degraded tropical site. Journal of Vegetation Science 6:627-636.

Powers, R.F., Alban, D.H., Miller, R.E., Tiarks, A.E., Wells, C.G., Avers, P.E., Cline, R.G., Loftus, N.S. Jr, and Fitzgerald, R.O. 1990. Sustaining productivity in North American forests: problems and prospects In Gessel, S. P.; Lacate, D.S.; Weetman, G.F.; and Powers, R.F. (eds.) Proceedings of the Seventh North American Forest Soils Conference; 1988 July 24-28; Vancouver, British Columbia, 49-79. University of British Columbia Vancouver.

Sim, B.L. and Nykvist, N. 1991. Impact of forest harvesting and replanting. Journal of Tropical Forest Science 3:251-284.

Smethurst, P.J. and Nambiar, E.K.S 1990a. Distribution of carbon and nutrients and fluxes of mineral nitrogen after clear-felling Pinus radiata. Canadian Journal of Forest Research 20: 1490-1497.

Smethurst, P.J. and Nambiar, E.K.S. 1990b. Effect of contracting silvicultural practices on N supply to young radiata pine. In: Dyck, W.J. and Mees C.A. (eds.) Proceedings IEA/BE A3. Impact of intensive harvesting on forest site productivity, 85-96. Bulletin No. 159. Forest Research Institute, Rotorua, New Zealand.

Spaargaren, O.C. and Deckers, J. 1998. The world reference base for soil resources - an introduction with special reference to soils of tropical forest ecosystems. In: Schulte, A and Ruhiyat D. (eds.) Soils of tropical forest ecosystems - characteristics, ecology and management, 21-28. Springer, Berlin.

Sunderlin, W.D. and Resosudarmo, I.A.P. 1996. Rates and causes of deforestation in Indonesia: towards a resolution of the ambiguities. Occasional Paper No. 9. CIFOR, Bogor, Indonesia.

Wenzel, W.W., Unterfrauner, H., Schulte, A., Ruhiyat, D., Simorangkir, D., Kuraz, V. and Blum. W.E.H. 1995. Physical properties of soils under different forest land use in East Kalimantan, Indonesia. In: Proceedings International Congress on Soils of Tropical Forest Ecosystems, 29 October-3 November 1995, Balikpapan, Indonesia, Vol 1: 135-153. Mulawarman University Press, Samarinda. 